Article

\title{
Countermeasure Analysis on Promoting Drinking Water Safety in Shanshan County, Xinjiang Autonomous Region, China
}

\author{
Weiwei Shao ${ }^{1}\left(\mathbb{D}\right.$, Jiahong Liu ${ }^{1, *(\mathbb{D})}$, Haixing Zhang ${ }^{2}$, Dianyi Yan ${ }^{1}$ and Weijia $\mathrm{Li}^{3}$ \\ 1 State Key Laboratory of Simulation and Regulation of Water Cycle in River Basin, \\ China Institute of Water Resources and Hydropower Research, Beijing 100038, China; \\ shaoww@iwhr.com (W.S.); yandy@iwhr.com (D.Y.) \\ 2 North China Municipal Engineering Design \& Research Institute Co., Ltd. Beijing Branch, \\ Beijng 100081, China; zhx112700@163.com \\ 3 School of Urban Planning and Environmental Science, Liaoning Normal University, Dalian 116029, China; \\ lwj1059872004@163.com \\ * Correspondence: liujh@iwhr.com; Tel.: +86-10-6878-1936
}

Received: 30 June 2018; Accepted: 30 July 2018; Published: 2 August 2018

\begin{abstract}
In recent years, China has paid an increasing amount of attention to improving urban and rural drinking water safety, an important aspect of building a healthy and stable society. This study analyzed countermeasures to promote drinking water safety in Turpan City of Shanshan County, in the Xinjiang Autonomous Region. First, we considered the current state of drinking water safety in Shanshan, including issues such as pollution, outdated water treatment technologies, leakage in the water supply pipe network, insufficient emergency management capability in urban areas, and low water supply guarantee rates in rural areas due to poor construction standards. Second, the quantity of guaranteed water resources was estimated; on this basis, an ideal distribution of regional water plants and water supply network needs for the optimal allocation of water resources is suggested. Third, a water purification program was developed to solve untreated water quality problems, including centralized and decentralized water quality treatments alongside intelligent water flow control processes. Water resource conservation and risk control measures are also proposed in order to promote the security of drinking water; equipment updates, and the establishment of an intelligent water management platform are also suggested.
\end{abstract}

Keywords: drinking water safety; water resources allocation; water purification project; pipe network construction; intelligent water management

\section{Introduction}

More than 1 billion people in urban and rural areas of the world do not have access to safe drinking water [1]. The social harmfulness of unsafe drinking water is apparent, bringing health risks to the public, sometimes resulting in death. In recent years, some countries have implemented better water conservation efforts to protect water resources, moving beyond the stage of pursuing economic development and entering the stage of ecological protection [2,3]. For example, in Germany, water conservation areas have been established everywhere in order to promote the safety of water resources; Berlin alone is divided into three levels of protection zones around the aquifer, forming a first-class protective belt $10 \mathrm{~m}$ around the water [4,5]. This well-protected water, after collection, must also be processed through sedimentation, filtration, and disinfection before entering households. In addition to protecting water resources and minimizing pollution, some countries have also formulated emergency plans and penalties to promote drinking water safety. These emergency plans 
include the assessment and reduction of potential vulnerabilities in drinking water sources, helping to protect against public health catastrophes, the formulation and exercise of emergency contingency plans for sudden accidents, and the development of new safety detection technologies to promote drinking water safety in urban and rural areas [6].

Thus, ensuring drinking water safety in urban and rural areas is an important part of social development and of safeguarding the fundamental interests of the general public. However, the security of urban and rural drinking water in northwest China is currently threatened owing to a series of problems in the water system's engineering and operation. The probability of water supply is low, the amount of available water is insufficient, water resources are polluted, and water purification and emergency capacities are relatively low [7]. To meet the central government's desire to further urban-rural development, it is necessary to further accelerate the establishment of drinking water safety projects for people and livestock in northwest China. Management system reforms for water supply projects need to be intensified, and improvements in long-term project operations and socialized services should be made. Moreover, strengthening the protection of water resources, assuring water quality, improving the living conditions and environment of rural residents, and increasing residents' health levels are also important in narrowing the gap between urban and rural areas and promoting the common development of the whole society [8].

Taking Shanshan County of the Turpan Area in the Xinjiang Autonomous Region as an example, this study aimed to improve the regional urban and rural guaranteed water supply rate, the qualification rate of water quality, the popularization rate of tap water in rural areas, and the overall operation and management of water projects. Measures such as improving the quality and efficiency of drinking water safety, promoting integrated management systems for urban and rural water supplies, and promoting comprehensive, coordinated, and sustainable eco-social development of urban and rural areas should be considered to build a model for ensuring drinking water safety in the counties of northwest China.

\section{Study Area and Data}

This study focused on Shanshan County of the Xinjiang Autonomous Region, which is located in northwest China. Shanshan County is at the southern foot of Bogda Mountain in the eastern Tianshan Mountains, south of the Turpan Basin. It lies between $\approx 89^{\circ} 30^{\prime} 28^{\prime \prime}-91^{\circ} 54^{\prime} 00^{\prime \prime} \mathrm{E}$ and $\approx 41^{\circ} 12^{\prime} 10^{\prime \prime}-43^{\circ} 33^{\prime} 00^{\prime \prime} \mathrm{N}$, with a total area of $39,500 \mathrm{~km}^{2}$. Shanshan County has a temperate inland desert climate with a mean annual rainfall of less than $26 \mathrm{~mm}$. The local river system consists of mountain streams: Ertanggou, Kekeya, and Karuqi from the west to the east (Figure 1). Owing to the tectonic uplift of Huoyan Mountain, Shanshan County is divided into two hydrogeological units: the northern and southern basins. Groundwater in the northern basin is dominated by a phreatic aquifer; that of the southern basin is dominated by a confined aquifer. Shanshan County has five townships, five towns, and a horticultural market. By the end of 2014, the county's total population had reached 242,700 , of which the agricultural population accounted for $74.90 \%$.

This study also collected related data on various social and economic indicators and on the development planning of water resources in Shanshan County, mainly through reference to the Statistics Bureau of Turpan Prefecture and Shanshan County. These data include the Statistical Yearbook of Turpan Prefecture, the Shanshan County Drinking Water safety and Network Transformation Report, and the overall planning of county development, land-use planning, and county water conservancy development planning [9-12]. When statistical data were lacking, field investigations and surveys were conducted; these data used were carefully reviewed and amended to ensure that the information used was accurate and scientific. 


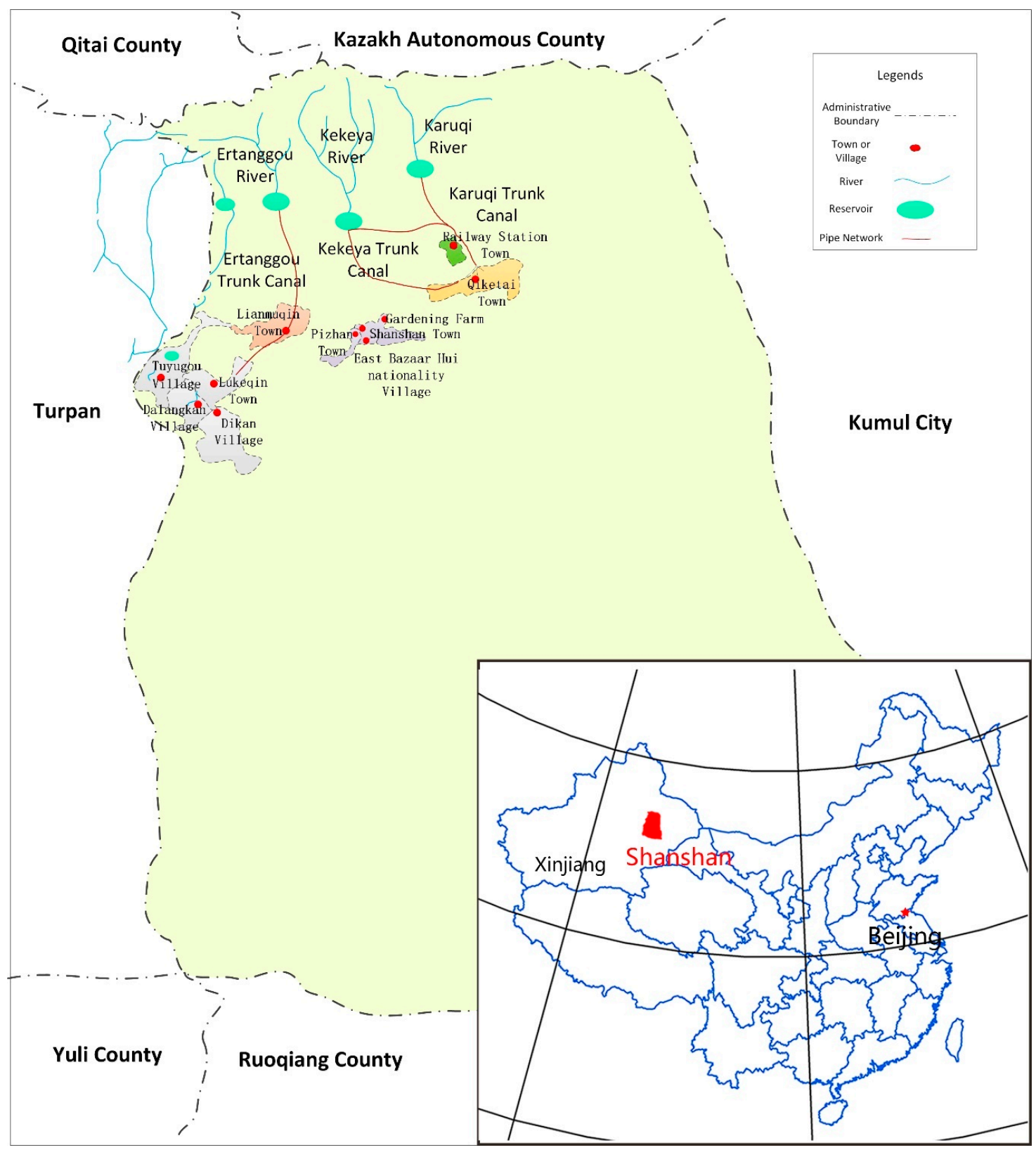

Figure 1. River system of Shanshan County.

\section{Analysis of Current Problems}

Current problems with drinking water safety in Shanshan County include insufficient water supply guarantee rate (less than 90\%), lack of convenient accessibility for taking water, a higher water supply pipe network leakage rate, varying degrees of water pollution, poor water purification treatment technology, insufficient water quality monitoring and detection ability, and poor emergency response systems.

\subsection{Water Supply Issues}

Water in Shanshan County is supplied by two water supply companies for the urban areas: The First Water Supply and Drainage Company and The Second Water Supply and Drainage Company. The water source of The First Water Supply and Drainage Company is groundwater. The Second Water Supply and Drainage Company's water source used to be deep underground well water [13], but has 
gradually changed to surface water. Shanshan's rural drinking water consists primarily of a centralized water supply that essentially covers all villages and towns. There are four primary waterworks: ShanNan, Qiketai, Suburban, and Lianmuqin. Ensuring drinking water safety in Shanshan is very serious (Table 1). Besides these centralized water supply projects, there are also some distributed water supply projects in rural areas. Most decentralized water supply is from wells dug to access water without facilities, which relies on shallow groundwater; surface water from ponds, gullies, or channels can also be utilized. In 2014, the number of people without safe drinking water in towns and villages was about 416,000 , accounting for $16.5 \%$ of the total population of the county. The current water supply faces issues including unreasonable utilization of water resources, aging of channel engineering and large loss of water supply, groundwater overexploitation, and poorly managed water projects.

Table 1. Centralized water supply projects in Shanshan County.

\begin{tabular}{|c|c|c|c|}
\hline & Waterworks & Coverage Area & Population Served \\
\hline \multirow{2}{*}{$\begin{array}{c}\text { Urban } \\
\text { Waterworks }\end{array}$} & The First Water Supply and Drainage Company & Urban area and its surrounding & 48,000 \\
\hline & The Second Water Supply and Drainage Company & Urban area and Railway Station town & 13,000 \\
\hline \multirow{2}{*}{$\begin{array}{c}\text { Rural } \\
\text { Waterworks }\end{array}$} & Qiketai Waterworks & Qiketai town and a part of Pizhan village & 16,064 \\
\hline & Lianmuqin Waterworks & Lianmuqin town and some oilfields & 34,174 \\
\hline
\end{tabular}

\subsection{Water Quality Issues}

The main problem for drinking water insecurity in Shanshan County is that water quality is not up to standards, with water pollution being primarily due to domestic sewage and industrial wastewater discharge. Water quality test results showed that, for two consecutive years, the total number of colony-forming units in $\approx 80-85 \%$ of the drinking water was beyond prescribed limits; furthermore, indicators of turbidity, chroma, chlorides, and total hardness levels were all above the limits set out in the 'Drinking Water Sanitary Standard (GB5749-2006)' and did not meet drinking water quality requirements (Table 2). The protection of drinking water sources and purification treatment of drinking water should be further strengthened.

Table 2. Water quality testing data from water plants during 2013-2014.

\begin{tabular}{|c|c|c|c|c|c|}
\hline Water Plants & Date & Unqualified Inspection Item & Limit & Testing Data & Detection Object \\
\hline \multirow{9}{*}{$\begin{array}{l}\text { ShanNan } \\
\text { Waterworks }\end{array}$} & \multirow{4}{*}{10 May 2013} & Total coliform group (MPN/100 L) & Not being detected & $>1600$ & \multirow{4}{*}{ Product water and tap water } \\
\hline & & Heat-resistant coliform (MPN/100 L) & Not being detected & $>1600$ & \\
\hline & & Particles visible to naked eye & - & Grains of sand & \\
\hline & & Chroma & 15 & 60 & \\
\hline & 5 June 2013 & Total bacteria colonies & $\leq 100$ & 540 & Tap water (Dikan Village) \\
\hline & 5 June 2013 & Total bacteria colonies & $\leq 100$ & 680 & Tap water (Tuyu Gully) \\
\hline & $\begin{array}{c}\text { 27 September } \\
2013\end{array}$ & Total bacteria colonies & $\leq 100$ & 547 & Tap water (Dikaner village) \\
\hline & 21 January 2014 & Total bacteria colonies & $\leq 100$ & 650 & Source water (Seerkefu Village) \\
\hline & 27 March 2014 & Heat-resistant coliform (MPN/100 L) & Not be detected & 46 & Tap Water \\
\hline
\end{tabular}


Table 2. Cont

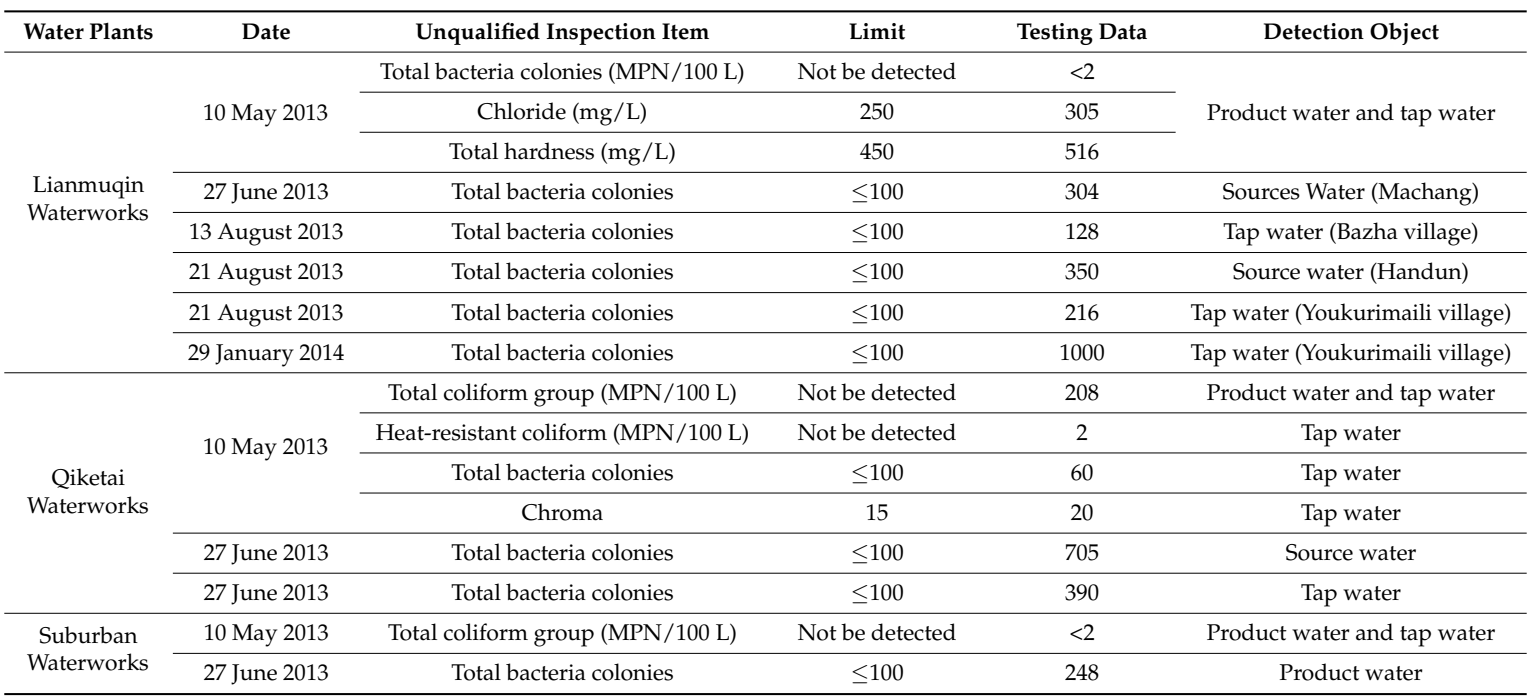

\section{Study Methods}

In this study, problems of water resources and project management were analyzed based on water quantity, water quality, and related management in the status quo of urban and rural drinking water safety in Shanshan County $[14,15]$. The research method was problem-oriented and designed to propose solutions to fundamentally solve drinking water safety issues [16] (Figure 2).

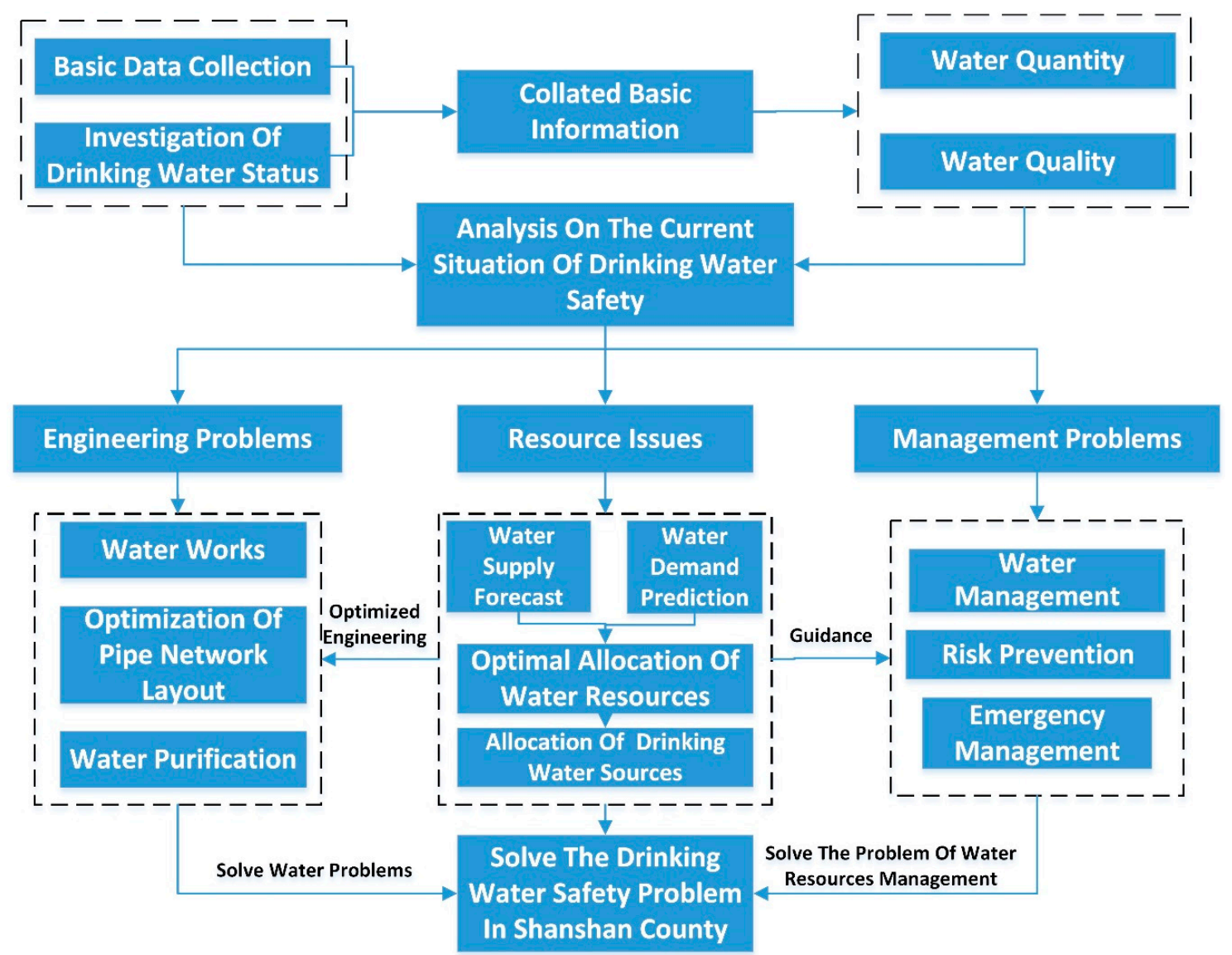

Figure 2. Technical route of the study methods. 


\subsection{Optimization Methods for Water Quantity and Quality}

According to the problems of water quantity and quality, optimized allocation of water resources is applied to guide the construction of waterworks and the optimization of pipe networks. Furthermore, the construction of water purification projects is strengthened to promote drinking water safety in urban and rural area.

\subsubsection{Allocation of Water Resources}

\section{(1) Supply of Water}

According to the distribution of water resources in Shanshan County, water resources can be classified into surface water resources and groundwater resources. In this area, surface water resources are mainly from rivers. Water resource zoning in the area was determined from the distribution of rivers, from which runoff depth contour maps can be drawn according to the rainfall-runoff relationship using data from hydrological stations. The annual runoff series can be deduced from the precipitation series, and the annual runoff depth contour map is plotted year by year. The surface runoff of each water resource district can be calculated, and the surface runoff series of various water resource districts are calculated according to the runoff depth contour map, and the frequency of the surface runoff can be calculated. Finally, the surface water resources of different frequencies (e.g., 20\%, 50\%, 75\%, 85\%, and $95 \%$ ) for each water resource district were obtained.

\section{(2) Forecast Water Demand}

Forecast water demand was determined by the scale of the population and the level of economic development. Recent and long-term development were predicted so that recent, medium-term, and long-term population and economic development scales could be determined. In addition, according to the scale of population and economic development, the annual water demands from residents, agriculture, industry, tertiary industry, and the ecological environment were analyzed for different levels of the hydrological year.

The quota method was adopted for the forecast of domestic water demand. Through reasonable forecasts of per capita water demand, the prediction of water demand was determined by combining the results of the estimation of urban and rural populations.

According to the annual development index of each target year and the corresponding water quota, the agricultural water demand was determined. Based on the adjustment of agricultural planting structure, the agricultural water demand of the Ertanggou, Kekeya, and Kanerqi irrigation areas, along with Shanshan County was computed. The forecasts of water demand for general industry and tertiary industry were calculated by a scale of ten-thousand-yuan production value. According to the survey of the status quo of actual water consumption among existing enterprise in Shanshan County, the water quota in each target year was determined based on the prediction results of the integrated water resources planning. Meanwhile, the water demand of industry in each target year was computed based on the prediction results of industrial and tertiary industrial development. The water demand for rivers mainly includes water demand for production in the rivers (e.g., fishery water and ecological water demands).

Lastly, according to the level of socio-economic water demand and the conditions of water resources development and utilization, the balance between current, recent, medium-term, and long-term supply and demand was analyzed and calculated.

\subsubsection{Optimization of Pipe Networks and Water Purification}

According to the prediction of precipitation, the available water supply of each district was determined; the distribution and quantity of the pipe network, including water delivery engineering and pipe systems, were determined according to the water resource allocation of Shanshan County. For those places where there are difficulties in extending the pipe network, only a decentralized water 
supply can be adopted. Appropriate water supply measures should be implemented according to local conditions; small independent water supply systems with water purification and disinfection facilities should be built in rural areas. Shallow groundwater areas should consider shallow water supply projects; mountain stream areas should use water diversion facilities. Besides these, Karez projects could be considered as an optional scheme for places where water supply networks are hard to lay and popularize; Karez projects for water intake facilities have a long history in the Turpan area of Xinjiang Autonomous Region and involve engineered underground structures largely consisting of shafts, underground channels, surface channels, and flood ridges (small reservoir) with four parts. Karez projects are horizontal water collecting facilities for the exploitation and utilization of groundwater; they are suitable for both foothills and alluvial fans. Abundant snow and rain fall in valley areas of the northern and western Turpan basin during spring and summer; this precipitation supplements the phreatic Gobi aquifer. Karez projects are mainly used to intercept underground phreatic water with the aid of a slope, with the water then used for irrigation and residents' domestic water use. In Shanshan County, Karez projects could be used as a supplement in areas where there are water shortages or where water resource development and utilization is difficult. Since the 1970s, owing to the development of underground water, the utilization of the Karez projects has been significantly reduced; many Karez projects have dried up. In 2014, 84 Karez projects remained in Shanshan County (Figure 3), of which only 77 remain in a state of validity with running water discharge; the total annual runoff of Karez projects is about 69 million $\mathrm{m}^{3}$ and the water supply is about $45 \mathrm{million}^{3}$. Karez projects are mainly concentrated downstream of Dikan township, Lukqin town, and Tuyu Gully township; there is also some Karez mining in area of Qiketai.

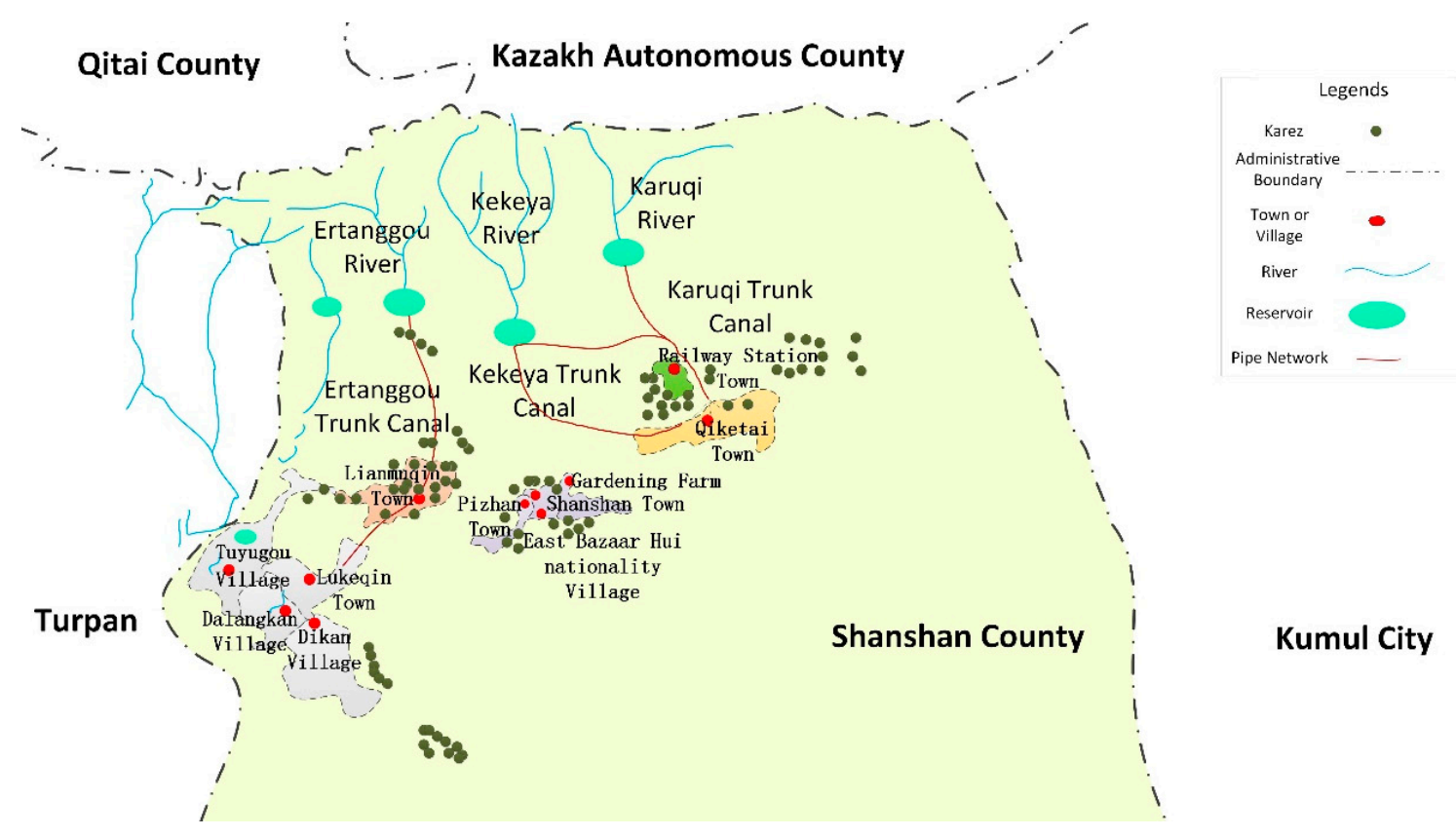

Figure 3. Distribution of Karez projects in Shanshan County.

\subsection{Water Protection and Management}

The protection of water sources must be strengthened and risk prevention must be applied to promote the safety of water supply. Through integrated strategies of engineering, technology, and management, the construction of drinking water safety projects in urban and rural areas is promoted by implementing equalization of projects, modularization of equipment, interconnected management, and the interconnection of equipment. 


\section{Results}

\subsection{Water Resources and Optimal Water Supply Allocation}

Through analysis of available surface water and groundwater supply at Shanshan, as well as the current state of water supply projects, the status of the water supply in the region was evaluated. It was also necessary to forecast socioeconomic conditions in the region, including the future water demands of residents, agriculture, industry, and tertiary industries [17]. Taking water savings in production and domestic usage into account, water resources were allocated between water use units and water users (domestic, industry, agriculture, animal husbandry, fisheries, and ecology) following optimal allocation (Table 3). At a hydrologic frequency of 50\% (almost a long-term average level), the actual current water supply is $4.218 \times 10^{8} \mathrm{~m}^{3}$, of which $1.069 \times 10^{8} \mathrm{~m}^{3}$ is overexploited; groundwater over-mining is even more serious during dry years. By 2020, water sources are planned to be broadened, and water use in agriculture and industry (especially agriculture) is anticipated to be reduced by, for example, further developing agricultural water saving facilities to improve water-use efficiency. The optimal allocation of water resources among the various water-use units enables a more adequate domestic water supply and provides water safety for urban and rural drinking water. The balance of water supply and demand in Shanshan is shown in Table 1.

Table 3. Supply and demand balance table for current and planned years in Shanshan under $50 \%$ frequency $\left(10^{5} \mathrm{~m}^{3}\right)$.

\begin{tabular}{|c|c|c|c|c|c|c|}
\hline \multirow{2}{*}{ Source of Water } & \multirow{2}{*}{ Type } & \multirow{2}{*}{$\begin{array}{c}\text { Current Year Allocation } \\
\text { Shanshan }\end{array}$} & \multicolumn{4}{|c|}{ Optimal Allocation of Planning Year } \\
\hline & & & Ertanggou & Kekeya & Karuqi & Shanshan \\
\hline \multirow{7}{*}{ Surface Water } & Domestic water & 42.88 & 48.50 & 0.00 & 0.00 & 48.50 \\
\hline & Conventional farmland & 1147.59 & 131.27 & 382.82 & 46.33 & 560.42 \\
\hline & Conventional garden & 4802.16 & 833.32 & 1415.20 & 98.58 & 2347.09 \\
\hline & Efficient farmland & 2295.72 & 720.99 & 1420.14 & 280.77 & 2421.89 \\
\hline & Fishery water & 48.00 & 18.00 & 15.00 & 15.00 & 48.00 \\
\hline & Ecological water use & 32.20 & 8.90 & 10.00 & 23.40 & 42.30 \\
\hline & Subtotal & $14,325.64$ & 4080.09 & 6062.09 & 1570.47 & $11,712.65$ \\
\hline \multirow{6}{*}{ Groundwater } & Domestic water & 808.65 & 436.54 & 328.32 & 152.92 & 917.78 \\
\hline & Industrial water & 983.75 & 122.56 & 241.49 & 570.01 & 934.07 \\
\hline & Animal husbandry water & 79.73 & 28.08 & 29.72 & 21.92 & 79.73 \\
\hline & Fishery water & 0.00 & 0.00 & 0.00 & 0.00 & 0.00 \\
\hline & Ecological water use & 289.80 & 80.10 & 90.00 & 210.60 & 380.70 \\
\hline & Subtotal & $27,850.03$ & 9300.74 & 9094.83 & 3749.91 & $22,145.48$ \\
\hline \multicolumn{2}{|c|}{ Total water supply } & $42,175.67$ & $13,380.83$ & $15,156.92$ & 5320.38 & $33,858.13$ \\
\hline \multicolumn{2}{|c|}{ Groundwater Overdraft } & $10,685.14$ & 2434.78 & 1198.98 & 1346.83 & 4980.59 \\
\hline
\end{tabular}

\subsection{Waterworks and Pipe Network Optimization Layout}

On the basis of water supply source protection, the layout and design of urban and rural waterworks and a water supply network were optimized [18]. The scale of the rural tap water supply was calculated by considering the water for domestic use in rural areas, the water for livestock use, the water for township enterprises, the amount of water leaked from the pipe network, and the amount of water consumed by waterworks; the urban tap water supply size calculation considered urban domestic water, industrial water, and the use of the waterworks themselves. By the rural water supply estimation, the total water supply of the two waterworks in the towns should be up to $9700 \mathrm{~m}^{3} / \mathrm{day}_{\text {, }}$ and the total water supply of the four water plants in rural areas should reach $18,700 \mathrm{~m}^{3} /$ day by 2020 (Figures 4 and 5). Considering the rapid population growth in the region, the existing waterworks 
will need to be rebuilt in the near future to fully meet the expanding needs. When conditions permit, the industrial and domestic water supply may also be realized in a decentralized manner to reduce water supply costs. Investigations have shown that the Shanshan water main line pipe network basically covers the whole territory, so the future pipe network extension will be based mainly on branch pipe networks and the pipe network to each house.

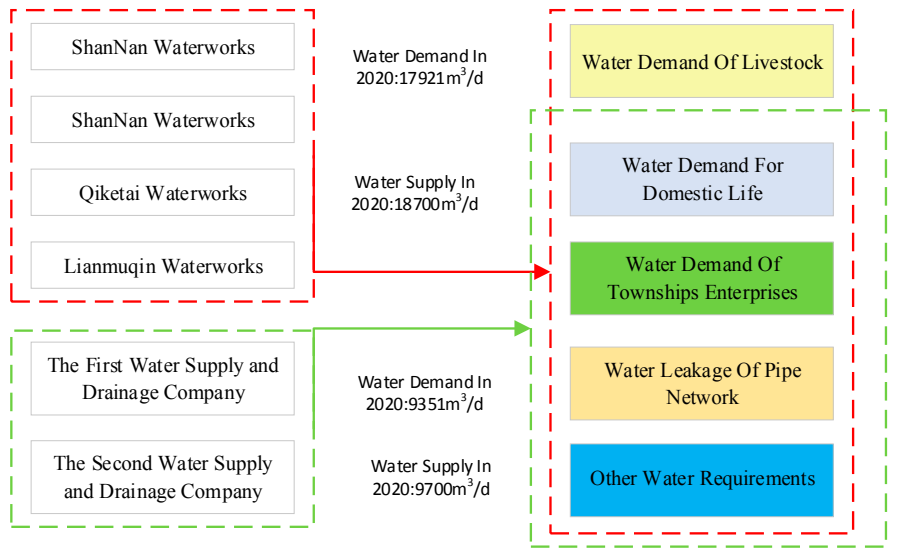

Figure 4. Structure of water supply and demand for the waterworks.

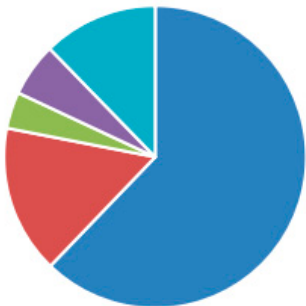

(a) ShanNan Waterworks

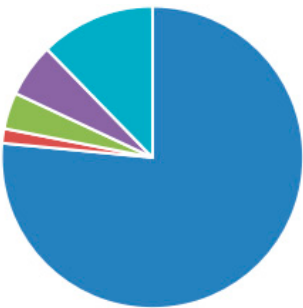

(c) Qiketai Waterworks

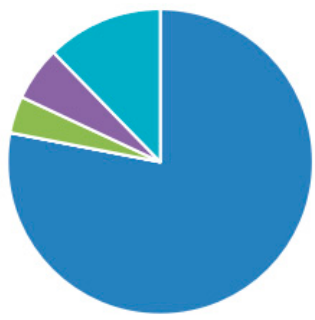

(e) The First Water Supply and Drainage Company

- Water demand for living

- Water demand of township enterprises

n Other water requirements

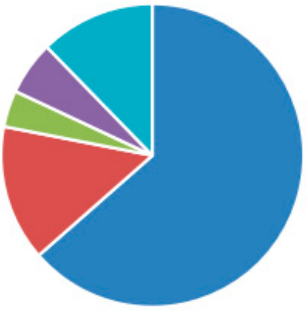

(b) Suburban Waterworks

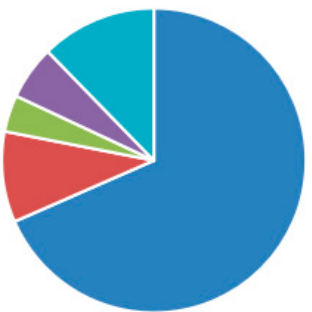

(d) Lianmuqin Waterworks

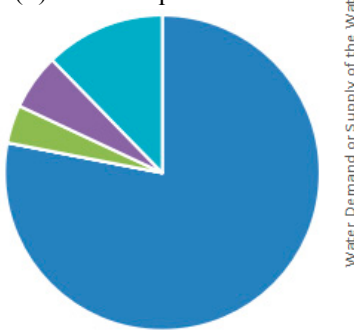

(f) The Second Water Supply and Drainage Company

- Water dem and of livestock

- Water leakage of pipe network

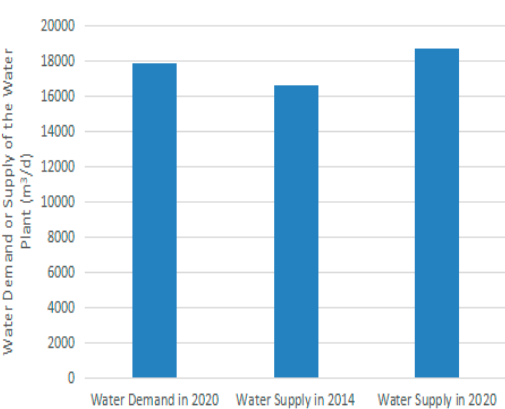

(g) Water demand and water supply of

four waterworks in villages and towns

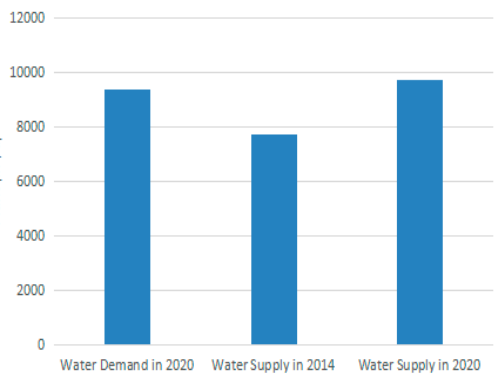

(h) Water demand and water supply of two waterworks in the urban areas

Figure 5. Water supply and demand prediction in 2010 for the six waterworks of Shanshan County. 
The decentralized water supply can be adopted for those places where there are difficulties in extending the pipe network. Appropriate water supply measures should be implemented considering local conditions. For example, in rural areas where the population is concentrated, small independent water supply systems with supporting water purification and disinfection facilities should be built. For shallow groundwater areas, a shallow water supply project could be adopted for domestic water use; however, reasonable exploitation of groundwater should also be taken into account. In rural areas where mountain streams are available, water diversion facilities could be developed for broadening sources of water.

Karez projects could be used in rural areas that encounter water shortages or where water resources are difficult to develop and utilize. Currently, Karez projects provide artificial discharge of groundwater in Shanshan County by extracting phreatic water, mainly for the daily needs of residents and for agricultural irrigation. A Karez project generally includes dozens to hundreds of shaft wells (Figure 6). In Shanshan County, the density of shaft wells is about $45 \mathrm{~km}^{-1}$ and the average interval of shafts is about $22 \mathrm{~m}$. With the control of groundwater exploitation in the future, there will not be a significant reduction in the prediction runoff of Karez projects in Shanshan County. However, Karez projects are only a supplementary form of decentralized water supply and the guarantee rate of their water quantity is insufficient; therefore, residents' domestic water supply cannot depend on Karez projects. At present, the water quality of Karez projects in Shanshan County is relatively good, meeting the groundwater quality (GB/T14848-93) class III standard (Table 4). Furthermore, the evaluation of microelements, toxicological indicators, and microbiological indicators in water samples from the Karez project also meets the requirements of Drinking Water Sanitary Standard (GB5749-2006).

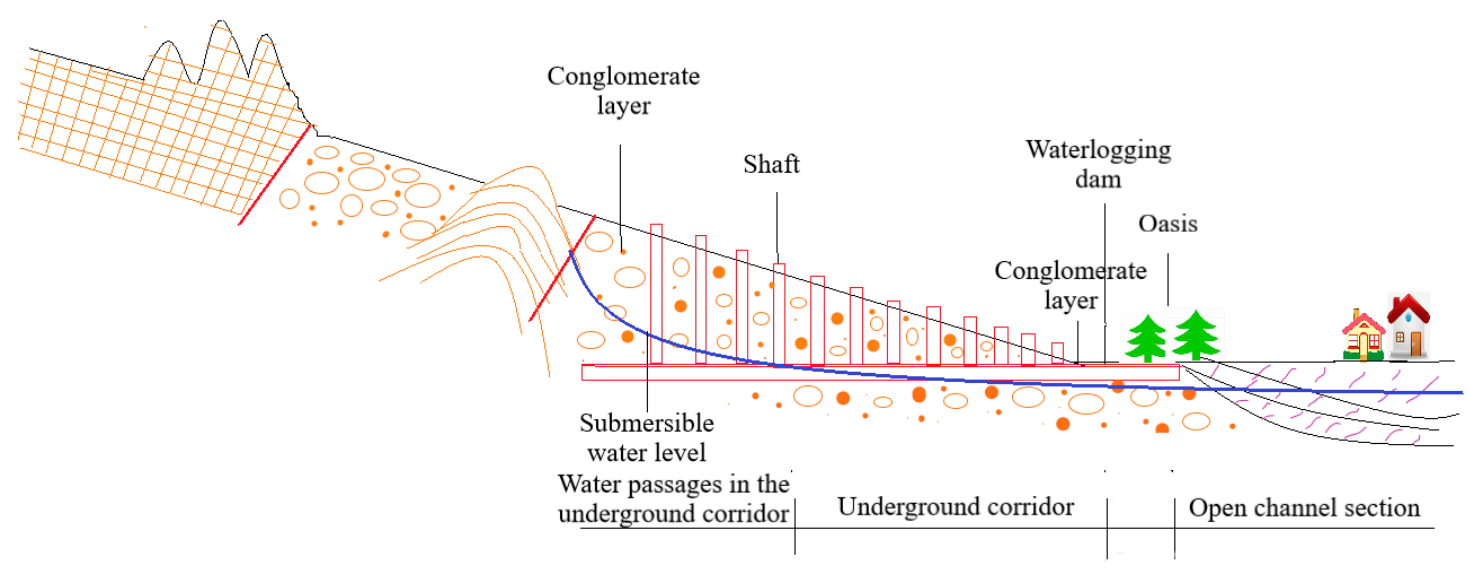

Figure 6. Schematic diagram of Karez well structures.

Table 4. Water quality monitoring and evaluation of the Karez project in Lianmuqin town.

\begin{tabular}{cccc}
\hline Monitoring Project & Standard Limit & Monitoring Value & Evaluation \\
\hline $\mathrm{pH}$ & $\approx 6.5-8.5$ & 8.37 & Qualified \\
Fluoride & $\leq 1.0$ & 0.18 & Qualified \\
Chloride & $\leq 250$ & 146.42 & Qualified \\
$\mathrm{Cr}^{6+}$ & $\leq 0.05$ & 0.004 & Qualified \\
Cyanide & $\leq 0.05$ & 0.004 & Qualified \\
Volatile phenol & $\leq 0.002$ & $<0.002$ & Qualified \\
Hardness & $\leq 450$ & 208.89 & Qualified \\
Sulphate & $\leq 250$ & 103.15 & Qualified \\
$\mathrm{NH}_{3}-\mathrm{N}$ & $\leq 0.2$ & 0.055 & Qualified \\
$\mathrm{NO}_{3}-\mathrm{N}$ & $\leq 20$ & 0.62 & Qualified \\
$\mathrm{NO}_{2}-\mathrm{N}$ & $\leq 0.02$ & 0.003 & Qualified \\
\hline
\end{tabular}


Table 4. Cont.

\begin{tabular}{cccc}
\hline Monitoring Project & Standard Limit & Monitoring Value & Evaluation \\
\hline $\mathrm{KMnO}_{4}$ & $\leq 3.0$ & 0.53 & Qualified \\
$\mathrm{Hg}$ & $\leq 0.001$ & 0.00005 & Qualified \\
$\mathrm{As}$ & $\leq 0.05$ & 0.0016 & Qualified \\
$\mathrm{Cd}$ & $\leq 0.01$ & 0.001 & Qualified \\
Total Coliforms & $\leq 3.0$ & 0 & Qualified \\
Total dissolved solid & $\leq 1000$ & 776 & Qualified \\
$\mathrm{Cu}$ & $\leq 1.0$ & 0.05 & Qualified \\
$\mathrm{Fe}$ & $\leq 0.3$ & 0.03 & Qualified \\
$\mathrm{Mn}$ & $\leq 0.1$ & 0.01 & Qualified \\
$\mathrm{Pb}$ & $\leq 0.05$ & 0.01 & Qualified \\
$\mathrm{Zn}$ & $\leq 1.0$ & 0.05 & Qualified \\
\hline
\end{tabular}

\subsection{Water Purification Project Design}

Our analysis revealed that the area's current water treatment technology is relatively poor, water quality is not up to standards, and the degree to which water treatment is automated is low. The design of water purification projects should include hydroinformatic technologies such as the automated control of a plant's operating processes, water purification processes, and online water monitoring applied through the internet, the Internet of Things, and cloud computing technology.

\subsubsection{Equipment and Modularization of the Water Purification Project}

Traditional drinking water projects often suffer from high workloads, high operating costs, and difficult maintenance; integrated water purification engineering facilities, however, are suitable for areas that lack water resources, have varied water pollution types, or are economically underdeveloped. Standard modular design can be used for different water quality and construction conditions and can handle a variety of water pollution problems comprehensively. Each module can be highly integrated through structural optimization to minimize occupied space (Figure 7). One centralized water supply plan is to select a centralized water source with standardized water quality and stable water volume and supply the water via a distribution network. A centralized water supply plan should be adopted in areas with relatively large populations and high water demand such as Shanshan.

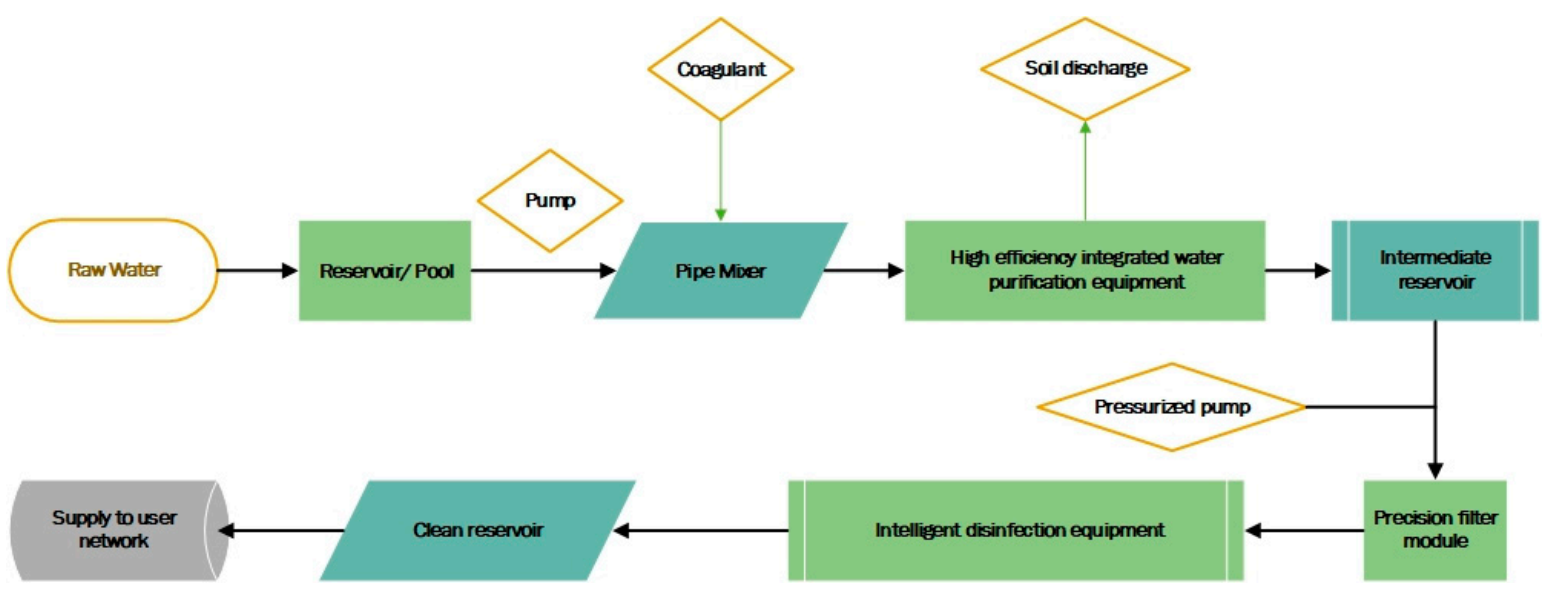

Figure 7. Processing flowchart for a centralized water supply program.

In this type of water supply plan, untreated water enters a reservoir through a water intake structure; the reservoir plays a role in adjusting the water quality and quantity. After that, water in the reservoir is lifted by a water pump to enter subsequent treatment units. A coagulant is added to the water before it enters a pipeline mixer so that colloids, suspended solids, microorganisms, and other 
organic and inorganic matter in the untreated water will be flocculated through the adsorption of an electric compression layer and bridge formed by the coagulant. Then, water enters high-efficiency integrated water purification equipment for further flocculation reactions (Figure 7). Later, separation, precipitation, filtrations, and water substance removal will be conducted. Fully automatic operation of the equipment is important for achieving fully automatic management of the water plant.

The intermediate reservoir also plays a role in regulating water quantity and quality. Water in the intermediate reservoir is also lifted by the booster pump to enter the subsequent treatment unit, which is a precision filter module. During the screening process by an ultrafiltration membrane, the pressure difference between the two sides of the membrane acts as a driving force, and the ultrafiltration membrane acts as a filter medium. When water flows through the surface of the membrane, only water and small molecules can pass through the micro-pores, which are closely set on the membrane surface forming a permeable liquid. This process helps to achieve successful purification, separation, and concentration of water.

Intelligent disinfection equipment, which is fully automatic and mainly contains chlorine dioxide, is used for sterilization. Chlorine dioxide is a highly effective disinfectant (sterilizer) that is recognized internationally as a chlorine disinfectant [19]. It can kill all microorganisms, including bacterial propagule, bacterial spores, fungi, mycobacteria, and viruses. Chlorine dioxide has strong adsorption and penetration abilities with regard to cell walls and can effectively oxidize enzymes containing the sulfhydryl group in cells; it can also rapidly inhibit microbial protein synthesis to destroy microorganisms [20]. Overall, the main advantage of chlorine dioxide disinfection is that it has nothing to do with the $\mathrm{pH}$ of the reaction. In comparison with pure chlorine, across a $\mathrm{pH}$ range of $\approx 5-9$, chlorine dioxide will cause microorganisms to lose activity at the same rate; furthermore, its disinfection efficiency is higher than pure chlorine. Chlorine dioxide has a stable bactericidal efficiency within the $\mathrm{pH}$ range of water treatment. Compared with ozone, chlorine dioxide disinfection has a very low cost of use, its generator is simpler to operate than the ozone generator, and maintenance costs are very low. At the same time, the stability of chlorine dioxide disinfection is higher than that of ozone [21]. On this basis, we chose chlorine dioxide as the most suitable disinfection device. The intelligent disinfection equipment consists of a main engine, a material tank, a water ejector, and a pressure gauge with electric contacts. If users have certain requirements, the device can be automated and networked by customizing a related program.

This decentralized water supply plan could be adopted in local areas that suffer from specific pollutants. The decentralized water supply scheme is a water supply mode for the existence of special pollutants in local areas, and water works and pipe networks are set up in the village as a unit to achieve the purpose of water supply by different water qualities, or to improve water treatment equipment for small water plants for standard-exceeding water quality, so as to solve the problem of drinking water for the residents. When different water quality problems need to be considered, the treatment steps may include a high-fluorine water treatment process, a brackish water treatment process, and a water treatment process for iron and manganese removal.

\subsubsection{Project Management Instrumentation and Intelligence}

\section{(1) Automatic Control System of the Waterworks' Operational Process}

The automatic control system in the water plant operation process adopts a high-performance, programmable main controller, which constitutes a secure and stable industrial network control system. The system consists of an intelligent water access terminal, an intelligent water terminal, an intelligent water supply terminal, a water quality monitoring terminal, a pipe network monitoring terminal, and a water control terminal.

The intelligent water intake terminal is installed in the water source or the water intake terminals of the waterworks for real-time monitoring and protection of the water intake equipment, and water is delivered from the water source or the water intake terminal to the water purification system. The waterworks water purification system utilizes the intelligent water-making terminal by integrating 
process requirements, which can automatically and intelligently regulate the operation of water purification devices as well as monitor and protect the devices in real time. The water supply terminal is equipped with an intelligent water supply terminal that can intelligently control the water supply devices to supply qualified water to users through constant pressure or constant flow and can monitor and protect the water supply devices at the same time. The water intake terminal, the water supply terminal, and the pipe network of the waterworks are equipped with the intelligent water quality monitoring system, which monitors water quality indicators in real time. The pipe network within the water supply scope of the waterworks has a pipe network monitoring terminal that monitors the running status of the pipe network and transfers the pipe network operating data back to the central control room in real time to achieve quantitative management of pressure and flow for the water supply. The water control terminal monitors water pressure and water flow for users in real time to ensure satisfaction of users' demands.

\section{(2) Intelligent Control of the Water Purification Process}

Intelligent control technology for the water purification process organically combines automatic control technology, intelligent monitoring, and management technology, forming an integrated solution of an intelligent control system for the water purification plant (Figure 8). Water quality parameters are promptly displayed. With the networking module, the water quality parameters of water sources in Shanshan can be monitored in real time, displayed, and stored in a personal computer (PC) in the network center room and the smart water platform. Shanshan's six water plants apply real-time monitoring during production, and the water purification process is dynamically shown through images on a PC that displays changes in the water quality index, the water purification process, the equipment status, the water flow direction, and the water supply data. Through the accumulation and analysis of data, the real-time trend curve and the historical trend curve can be generated as needed.

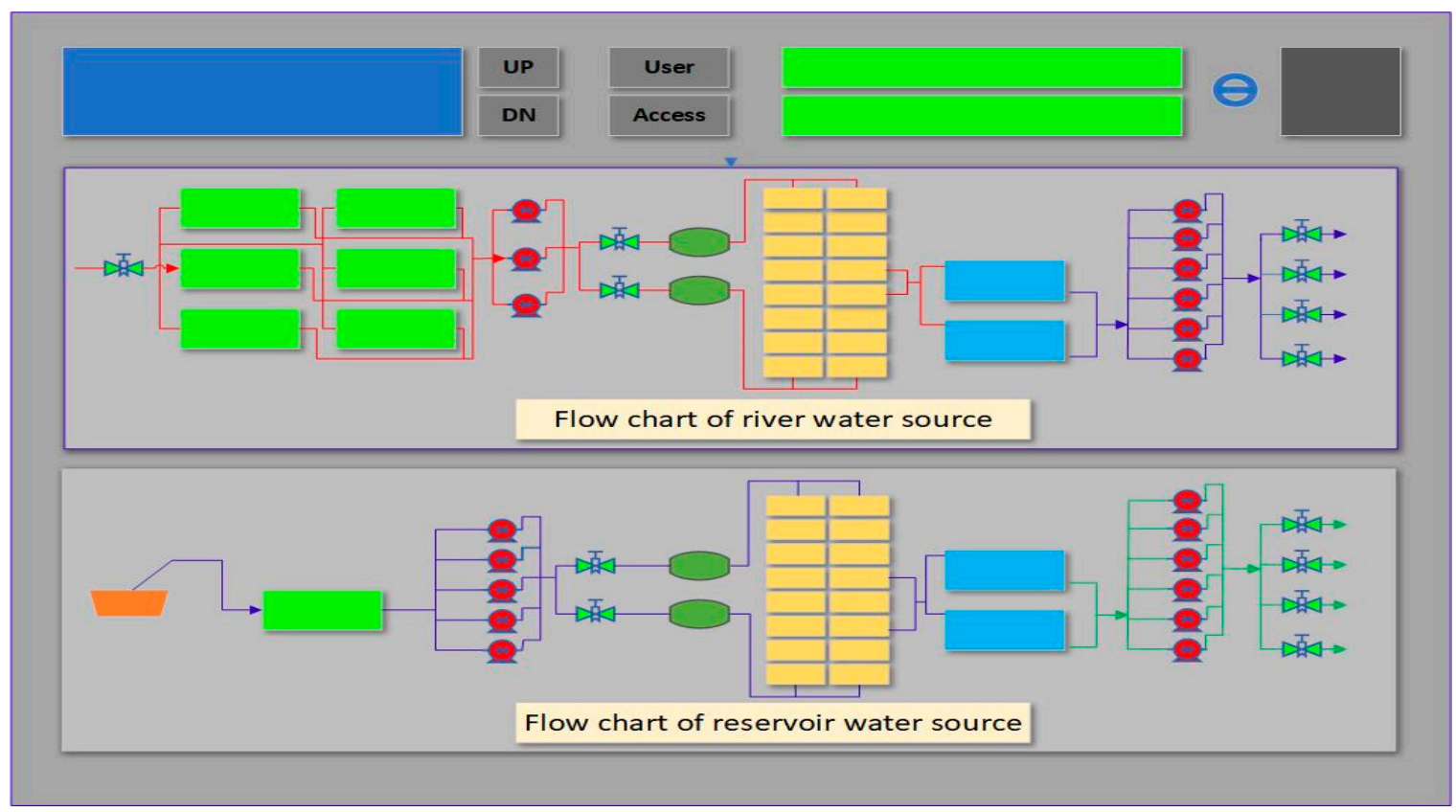

Figure 8. Schematic of real-time monitoring and control system.

Waterworks in Shanshan automatically collect data about the water purification process and generate statistical analysis reports with the intelligent control system. The data reports can be exported at any time, which provides first-hand information for water plant management decision-making. The Shanshan Central Control Room has set alarms for abnormality, fault, diagnosis, and failures in 
the water quality monitoring system, equipment, or pipeline; this facilitates timely management and helps to avoid potential problems.

(3) Intelligent Online Water Monitoring System

An intelligent online water monitoring system employs Internet of Things (IoT) technology to improve the level of automation (Figure 9). An intelligent water online monitoring system includes the following:

- Online water quality monitoring of wells, water quality and the supply network.

- Real-time monitoring and feedback on water sources, with water pollution information sent in the form of text messages.

- Online monitoring of water levels, flow, pressure, turbidity, conductivity, $\mathrm{pH}$, dissolved oxygen, residual chlorine, toxicity, and other parameters to promote water supply safety. Among which, toxicity testing depends on biotoxicity testing for detecting water quality; the object of the toxicity experiment is luminescent bacteria, including Vibrio fischeri, Photobacterium phosphoreum, Vibrio qinhaiensis, and so on. It can detect toxic substances, including pesticides, herbicides, polychlorinated biphenyls (PCB), polycyclic aromatic hydrocarbons (PAH), heavy metals, biological toxicants, petroleum pollutants, protein inhibitors, respiratory system inhibitors, and other toxic substances and microorganisms.

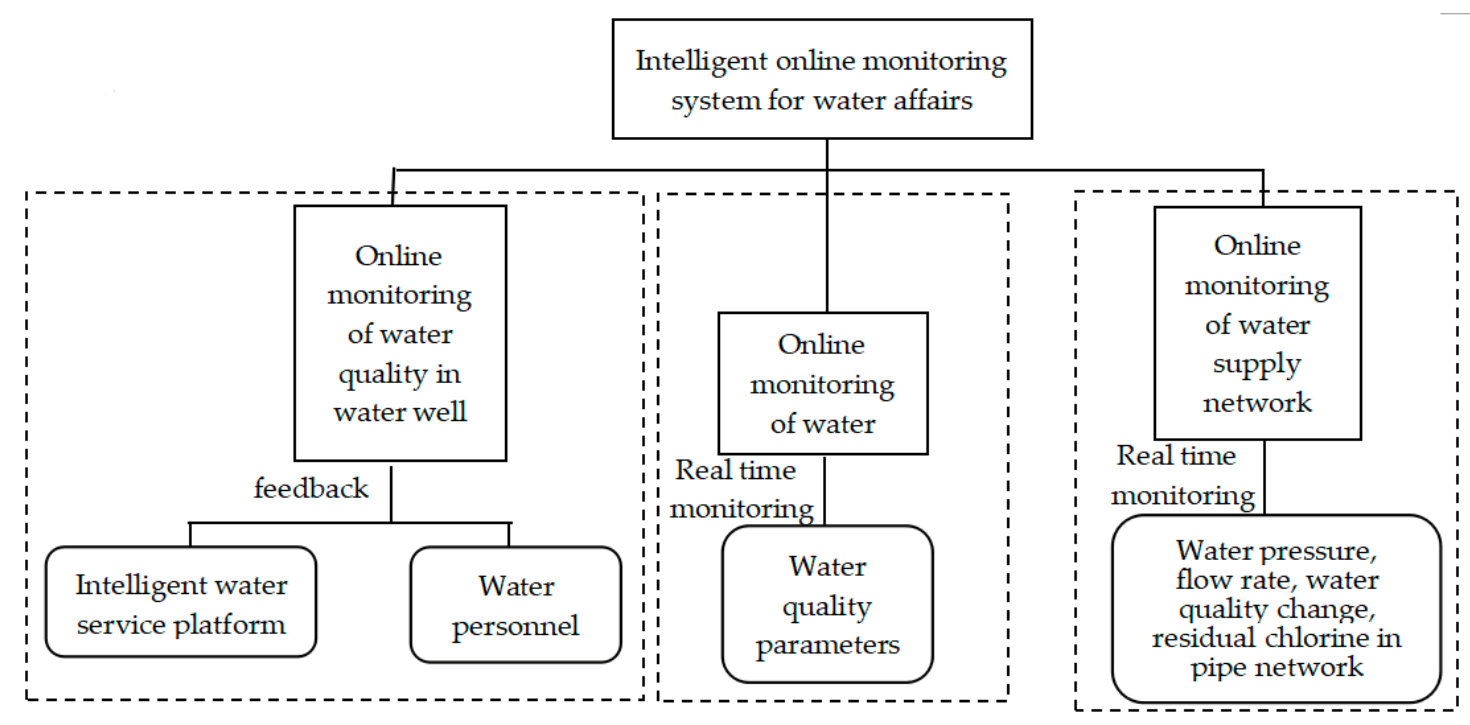

Figure 9. Flow chart of online monitoring system for intelligent water management.

Six waterworks control centers in Shanshan have dispatch information platforms. Targets for the next day are set based on daily pipe network data. By relying on these data, the platform generates scheduling solutions to assist in water network operational optimization scheduling management. Data are shared through the network, and the production scheduling data can be directly used in an office automation system to integrate monitoring, control, and management. At the same time, this intelligent online monitoring system has early warning and emergency management mechanisms in place for pollution incidents; there are based on the monitoring parameters. In terms of water quality in water source wells, we mainly monitor water intake flow, water intake pressure, water quality turbidity, electrical conductivity, $\mathrm{pH}$, water temperature, dissolved oxygen, toxicity, and other parameters that promote water intake safety from the source. In terms of water quality in the water supply network, we monitor water level in reservoirs, water supply flow, water pressure, turbidity, conductivity, $\mathrm{pH}$, dissolved oxygen, residual chlorine, toxicity, and other parameters to promote water supply safety in the six waterworks. In terms of the pipe network, we monitor the 
pressure, flow rate, and fluctuation of water quality and residual chlorine in the water supply network. Based on the monitoring parameters, when the early warning mechanism is set up, different algorithms can be selected. For example:

1. Simple algorithm: if one or more monitoring parameters exceed a certain reasonable threshold range, the system will automatically alarm and upload to the government management platform for assessment. After removing abnormal causes such as incorrect instrument detection or bad signals, it will be predisposed, allowing a government supervisor to check, conduct field sampling tests to judge the level of water pollution, and make corresponding emergency plans.

2. Complex algorithm: this is generally based on the comparison of different indicators at the same monitoring point in the same time period, the comparison of the same indicator at the same monitoring point in different time periods, the comparison of the same indicator at different monitoring points in the same time period, and the comparison of different indicators of different monitoring points in the same time period. This approach allows for the assessment of water pollution events after algorithm analysis, and provides information to the water management department allowing them to plan and made decisions.

In general, combined with the Internet of things (IoT) module, the spatial and attribute data of the water supply network and drainage are taken as core components with advanced computer software technology, communication technology, and graphics processing technology. With this information, a timely and stable emergency management alarm system can be established. Using a large amount of collected data, statistical analysis of water quality is conducted to provide decision support for the treatment of water pollution incidents and promote drinking water safety.

\subsection{Water Protection and Management}

Water conservation is a long-term and crucial goal for urban and rural societies. The Environmental Impact Assessment of building and planning projects provides many guidelines that should be adhered to in order to meet these goals. Based on the Assessment, new building projects that might pollute drinking water in protected areas are not allowed, and inspections of ongoing projects are necessary to mitigate and standardize pollution discharge. Agricultural sources of pollution should also be supervised; livestock and poultry breeding surveys can promote the use of organic fertilizer on farmland. Appropriate precautionary measures such as these can strengthen investment in infrastructure for drinking water sources. Solid waste, sewage, and garbage issues can be rectified, and the dynamic monitoring of groundwater and the development of Karez wells can be improved [22].

\section{Discussion}

With China's social and economic development, the urban water supply in China has been upgraded and improved; however, the water supply level in rural areas remains relatively imperfect, especially in the northwest region, where the water supply level of urban and rural areas differ significantly, and the management of rural drinking water is relatively backward. In this study, Shanshan County of the Xinjiang autonomous region was used as case study to consider the current water issues. This area has a low water supply guarantee rate and poor water quality treatment level, despite the fact that the water quantity and water quality joint management is integrated to promote drinking water safety in urban and rural areas. Generally speaking, based on the current situation and development demands of Shanshan County, a designed water supply scheme with integrated water quantity and water quality is needed to meet the needs of drinking water safety. In particular, the main advantage of this approach is that it provides a systematic solution.

Through the optimal allocation of water resources, this study described an approach that can meet the needs of water resource requirements for different sectors and promote the water requirement for drinking water in Shanshan County. Using engineering equipment and efficient automatic water treatment equipment, operation can be stable, while maintenance and repair remain convenient. 
By reducing the capital construction cost of reinforced concrete structures, the occupied area is also reduced. Although equipment is modularized, different treatments are carried out for different types and water qualities of raw water to improve integration and facilitate operation and maintenance. This approach would benefit from the upgrading and transformation of water plants and from the initiation of intelligent management of the waterworks. Through management is integrated, the system's operation equipment should be monitored by IoT. Through the PC or the intelligent water service platform of the central control room, water quality and water quantity change in the system, and the running state of the equipment and the pipe network can be monitored in real time, and remote management can be realized. Based on the intelligent combination of materials, the urban water supply system is run in real time through online monitoring equipment, such as the data mining instruments, the wireless network, and so on. This integrates the water management department with water supply facilities in a visual way to form an intelligent urban water service; it can carry mass water information for analysis and processing in a timely manner, assisting with decision-making suggestions. This system manages the production, management and service processes of the water supply system in a more precise and dynamic way, so as to achieve "wisdom".

Compared with other studies, which have mainly been limited to solving the problem of water quality in rural areas, this study proposes water quantity and quality joint management for drinking water supply in both urban and rural areas. In 2016, based on the scheme proposed in this study, Lianmuqin town of Shanshan County completed a concrete design and their system has already begun local trial operation. Through implementation, the drinking water supply quantity and water quality have all improved, and all 106 water quality indicators have reached those detailed in Drinking Water Sanitary Standard (GB5749-2006). Other studies, for example those in rural Yunnan Province and Inner Mongolia [23,24], have considered extensions of regional water supply pipe networks or solved the problem of exceeding the standard of water quality; in contrast, this study involved both of these approaches, and it also made full use of local advantages, such as utilization and protection of Karez projects for a decentralized water supply. The approach considered here also takes into account water supply and water quality treatment facilities and supports the modernization of drinking water safety management in the region.

\section{Conclusions}

Through the evaluation and prediction of water resources in Shanshan County, and a balance analysis of supply, demand, and optimal allocation, this study proposed countermeasures to ensure drinking water safety in Shanshan County. Comprehensive analysis of current of drinking water safety in urban and rural areas of Shanshan County was conducted. Optimal allocation of water resources was formulated temporally and spatially for reasonable and safe arrangement and utilization. Moreover, an integrated layout was designed for drinking water projects based on the overall terrain, hydrological conditions, status quo of water supply, and the quality of local drinking water sources. In addition, different management systems were developed according to the quantity and quality of water in each water source area, and the water pipe network and water purification system of Shanshan County was constructed and improved. Finally, the modernizations of the guarantee plan for drinking water safety was achieved (i.e., engineering equipment is equipped, equipment is modularized, management is integrated, and materials are combined intelligently). The drinking water safety scheme in the Shanshan County is a systematic solution for ensuring drinking water safety; it is also an intelligent development of integrated information resources, which would comprehensively improve the capabilities of water management and public services, enhance the quality of people's lives, and promote the clustering and development of related industries.

Author Contributions: Conceptualization, J.L.; Methodology, W.S. and H.Z.; Writing-original draft, W.S. and H.Z.; Writing-review \& editing, D.Y. and W.L.

Funding: This research was funded by the Chinese National key research and development program (2016YFC0401401); the CRSRI Open Research Program (CKWV2018494/KY); the Chinese National Natural 
Science Foundation (No. 51625904, No. 51522907, No. 51309245 and No. 51109222); the Research Fund of the China Institute of Water Resources and Hydropower Research (No. WR0145B502016, No. 2017ZY02).

Acknowledgments: The authors express sincere gratitude to the Jiangsu Maymuse Environmental Protection Technology Co., Ltd. for their cooperation in water purification study.

Conflicts of Interest: The authors declare no conflict of interest.

\section{References}

1. Ni, F.Q.; Liu, G.D.; Ren, H.Z.; Yang, S.C.; Ye, J.; Lu, X.Y.; Yang, M. Health Risk Assessment on Rural Drinking Water Safety-A Case Study in Rain City District of Ya'an City of Sichuan Province. J. Water Resour. Prot. 2009, 1, 128-135. [CrossRef]

2. Hoque, B.A.; Hallman, K.; Levy, J.; Bouis, H.; Ali, N.; Khan, F.; Khanam, S.; Kabir, M.; Hossain, S.; Alam, M.S. Rural drinking water at supply and household levels: Quality and management. Int. J. Hyg. Environ. Health 2006, 209, 451-460. [CrossRef] [PubMed]

3. Brick, T.; Primrose, B.; Chandrasekhar, R.; Roy, S.; Muliyil, J.; Kang, G. Water contamination in urban south India: Household storage practices and their implications for water safety and enteric infections. Int. J. Hyg. Environ. Health 2004, 207, 473-480. [CrossRef] [PubMed]

4. Clasen, T.F.; Thao, D.H.; Boisson, S.; Shipin, O. Microbiological Effectiveness and Cost of Boiling to Disinfect Drinking Water in Rural Vietnam. Environ. Sci. Technol. 2008, 42, 4255-4260. [CrossRef] [PubMed]

5. Oswald, W.E.; Lescano, A.G.; Bern, C.; Calderon, M.M.; Cabrera, L.; Gilman, R.H. Fecal Contamination of Drinking Water within Peri-Urban Households, Lima, Peru. Am. J. Trop. Med. Hyg. 2007, 77, 699-704. [CrossRef] [PubMed]

6. Bhatta, D.R.; Bangtrakulnonth, A.; Tishyadhigama, P.; Saroj, S.D.; Bandekar, J.R.; Hendriksen, R.S.; Kapadnis, B.P. Serotyping, PCR, phage-typing and antibiotic sensitivity testing of Salmonella serovars isolated from urban drinking water supply systems of Nepal. Lett. Appl. Microbiol. 2007, 47, 588-594. [CrossRef] [PubMed]

7. Dou, M.; Wang, Y.Y.; Li, C.Y. Oil leak contaminates tap water: A view of drinking water safety crisis in China. Environ. Earth Sci. 2014, 72, 4219-4221. [CrossRef]

8. Reddy, B.V.S.; Ramesh, S.; Kumar, A.A.; Wani, S.P.; Ortiz, R.; Ceballos, H.; Sreedevi, T.K. Bio-Fuel crops research for energy security and rural development in developing countries. BioEnergy Res. 2008, 1, 248-258. [CrossRef]

9. Bureau of Statistics of Turpan. Turpan Statistical Yearbook; China Statistics Press: Turpan, China, 2014.

10. Statistics Bureau of Xinjiang Uygur Autonomous Region. Xinjiang Statistical Yearbook; China Statistics Press: Xinjiang, China, 2014.

11. Bin, W.; Mingliang, D.; Pengnian, Y.; Yinglian, L. Relationship between groundwater recharge, discharge evolution and Karez flow attenuation in Shanshan County in nearly 60 years. Trans. Chin. Soc. Agric. Eng. 2016, 32, 102-108. [CrossRef]

12. Ping, L.; Minhua, G.; Jing, S.; Jie, L. Driven Forces to Landuse/Land Cover Change in Shanshan in Xinjiang. Resour. Environ. Eng. 2007, 21, 632-635. [CrossRef]

13. Jennifer, I.; Meine, P.D. Factors influencing selection of drinking water technologies for urban informal settlements in Kampala. Water Environ. J. 2014, 28, 423-433. [CrossRef]

14. Robert, H.; Michael, R. Risks and responses to universal drinking water safety. Philos. Trans. R. Soc. A Math. Phys. Eng. Sci. 2013, 371, 20120417. [CrossRef]

15. Lisa, R.M. Beyond improved access: Seasonal and multidimensional water safety in urban Philippines. Glob. Soc. Welf. 2015, 2, 119-128. [CrossRef]

16. Sara, N.; Mohammad, K.; Mohsen, Y.; Zahra, Z. Increasing water safety: An algorithm to improve water distribution performance. Water Resour. Manag. 2013, 27, 2903-2921. [CrossRef]

17. Li, C.L.; Zhou, J.Z.; Ouyang, S.; Wang, C.; Liu, Y. Water resources optimal allocation based on large-scale reservoirs in the upper reaches of Yangtze River. Water Resour. Manag. 2015, 29, 2171-2187. [CrossRef]

18. Afshar, M.H. Application of a max-min ant system to joint layout and size optimization of pipe networks. Eng. Optim. 2006, 38, 299-317. [CrossRef]

19. Barbeau, B.; Desjardins, R.; Mysore, C. Impacts of water quality on chlorine and chlorine dioxide efficacy in natural waters. Water Res. 2005, 39, 2024-2033. [CrossRef] [PubMed] 
20. López-Gálvez, F.; Gil, M.I.; Meireles, A. Demonstration tests of irrigation water disinfection with chlorine dioxide in open field cultivation of baby spinach. J. Sci. Food Agric. 2018, 98, 2973-2980. [CrossRef] [PubMed]

21. Junli, H.; Li, W.; Nenqi, R. Disinfection effect of chlorine dioxide on viruses, algae and animal planktons in water. Water Res. 1997, 31, 455-460. [CrossRef]

22. Arvanitoyannis, I.S.; Tserkezou, P.; Varzakas, T. An update of US food safety, food technology, GM food and water protection and management legislation. Int. J. Food Sci. Technol. 2006, 41, 130-159. [CrossRef]

23. Zhu, W.; He, H. Problems in rural drinking water projects in Yunnan province and Countermeasures for consolidation and improvement. Res. Dev. Water Conserv. 2016, 16. [CrossRef]

24. Zhao, L.S.; Zhou, Y.; Qu, B.L. Policy Review on strengthening construction and management of drinking water safety projects in rural areas. Water Conserv. Chin. 2014, 11, 4-5.

2018 by the authors. Licensee MDPI, Basel, Switzerland. This article is an open access article distributed under the terms and conditions of the Creative Commons Attribution (CC BY) license (http://creativecommons.org/licenses/by/4.0/). 